\title{
What Proportion of Female Sex Workers Practise anal Intercourse and How Frequently? A Systematic Review and Meta-analysis
}

\author{
Branwen Nia Owen ${ }^{1}\left(\mathbb{D} \cdot\right.$ Rebecca F. Baggaley $^{2} \cdot$ Jocelyn Elmes $^{1,2} \cdot$ Amy Harvey $^{1} \cdot$ Zara Shubber $^{1} \cdot$ Ailsa R. Butler ${ }^{1}$. \\ Romain Silhol $^{1} \cdot$ Peter Anton $^{3} \cdot$ Barbara Shacklett $^{4} \cdot$ Ariane van der Straten $^{5,6} \cdot$ Marie-Claude Boily $^{1}$
}

Published online: 5 April 2019

(c) The Author(s) 2019

\begin{abstract}
HIV is more efficiently acquired during receptive anal intercourse (AI) compared to vaginal intercourse (VI) and may contribute substantially to female sex workers' (FSW) high HIV burden. We aim to determine how common and frequent AI is among FSW globally. We searched PubMed, Embase and PsycINFO for studies reporting the proportion of FSW practising $\mathrm{AI}$ (prevalence) and/or the number of AI acts (frequency) worldwide from 01/1980 to 10/2018. We assessed the influence of participant and study characteristics on AI prevalence (e.g. continent, study year and interview method) through sub-group analysis. Of 15,830 identified studies, 131 were included. Nearly all $(\mathrm{N}=128)$ reported AI prevalence and few frequency $(\mathrm{N}=13)$, over various recall periods. Most studies used face-to-face interviews $(\mathrm{N}=111)$. Pooled prevalences varied little by recall period (lifetime: $15.7 \% 95 \% \mathrm{CI} 12.2-19.3 \%, \mathrm{~N}=30, \mathrm{I}^{2}=99 \%$; past month: $16.2 \% 95 \% \mathrm{CI} 10.8-21.6 \%, \mathrm{~N}=18, \mathrm{I}^{2}=99 \%$ ). The pooled proportion of FSW reporting $<100 \%$ condom use tended to be non-significantly higher during AI compared to during VI (e.g. any unprotected VI: $19.1 \% 95 \%$ CI 1.7-36.4, $\mathrm{N}=5$ and any unprotected AI: 46.4\% 95\%CI 9.1-83.6, $\mathrm{N}=5$ in the past week). Across all study participants, between 2.4 and $15.9 \%(\mathrm{~N}=6)$ of all intercourse acts (AI and VI) were anal. Neither AI prevalence nor frequency varied substantially by any participant or study characteristics. Although varied, AI among FSW is generally common, inconsistently protected with condoms and practiced sufficiently frequently to contribute substantially to HIV acquisition in this risk group. Interventions to address barriers to condom use are needed.
\end{abstract}

Keywords Anal intercourse $\cdot$ Female sex workers $\cdot$ Sexual behaviour $\cdot$ HIV

\section{Introduction}

HIV is very effectively transmitted during anal intercourse unprotected by condoms (UAI), with a meta-analysis finding that women may have an 18-fold greater HIV acquisition risk during UAI compared to vaginal intercourse unprotected by condoms (UVI) [1]. Thus, even a small proportion of intercourse acts being AI may therefore substantially contribute to HIV transmission [2, 3]. However, the role of

Peter Anton, Barbara Shacklett, Ariane van der Straten made an equal contribution to article.

Electronic supplementary material The online version of this article (https://doi.org/10.1007/s10461-019-02477-w) contains supplementary material, which is available to authorized users.

Branwen Nia Owen

b.owen11@imperial.ac.uk

Extended author information available on the last page of the article anal intercourse (AI) within heterosexual epidemics has not been sufficiently examined and is frequently overlooked [4]. For example, recent reviews on HIV risk behaviour among female sex workers (FSW) in China [5] and among young people in Africa [6] examined multiple measures of sexual risk-taking but neither included AI practice. Likewise, public health messaging to FSW on HIV transmission seems to routinely neglect AI practice. For example, none of the studies included in two systematic reviews on HIV prevention interventions among African FSW reported whether or not messaging on safe AI was included in the interventions $[7,8]$. This omission may contribute to the lack of awareness of transmission risk during AI among FSW [3, 9] and subsequently to condoms being used less consistently during AI compared to VI (vaginal intercourse) [3, 10].

The practice of AI among FSW has been reported in many articles. However, the extent to which $\mathrm{AI}$ is practised by FSW and how often it is practised by age, region and over time has yet to be comprehensively described. It is 
particularly pertinent to examine these patterns among FSW, compared to other population groups, as FSW experience a far greater burden of HIV and STI infection than women in the general population [11]. This review will be useful to improve our understanding of AI practices, inform prevention messages and identify knowledge gaps. Parameter estimates derived from this review can be used in mathematical models to explore the contribution of AI to the HIV epidemic and assess the influence of AI on the predicted effectiveness of prevention interventions.

In order to estimate the contribution of AI to HIV and STI incidence among FSW and transmission to their sexual partners, it is first necessary to accurately described AI practice in this group. To estimate this contribution, we need data on the proportion of FSW who practise AI and at what frequency, with which types of partner $\mathrm{AI}$ is practised and whether condoms are used [4]. The equivalent information for VI is required for a complete understanding of an individual's potential HIV risk through heterosexual sex. Our review aims to systematically review and summarise published estimates on the proportion of FSW reporting $\mathrm{AI}$ and the number of $\mathrm{AI}$ acts, and to examine the sources of variation in AI practice.

\section{Methods}

The systematic review was undertaken following PRISMA guidelines for reviews of observational studies [12].

\section{Search Strategy}

PubMed, Embase and PsycINFO were searched for Englishlanguage articles published 1st January 1980 to 31st October 2018 reporting on sexual behaviour among FSW (see Supplement A for full search terms). The screening of identified records was conducted by only one reviewer; with BNO conducting the search from 1990 onwards alone and JE from 1980 to 1989 . We did not include the term 'anal' in our search to avoid rejecting studies that, while eligible, did not refer to $\mathrm{AI}$ in the title or abstract. We discarded titles that were obviously irrelevant, then screened abstracts and retrieved fulltext articles if any sexual behaviour among FSW (defined as exchanging sexual services for payment, either cash or inkind) was reported. Bibliographies of included articles were scanned for further relevant articles. Studies were included in the review if they fulfilled the following criteria:

Published, peer-reviewed articles on cross-sectional studies, cohort studies or randomised control trials (RCTs) that reported data on FSW from which it was possible to extract or calculate the proportion practising $\mathrm{AI}$ and/ or the number of AI and UAI acts over any recall period.
Although grey literature can be useful, its inclusion can introduce difficulties in ensuring that the search is systematic and that the studies included are methodologically sound. We therefore chose to restrict our review to capture the highest quality peer-reviewed evidence available using an easily replicable search strategy.

\section{Data Extraction}

We defined a priori the variables to be extracted. We used a standard procedure to extract data to a spreadsheet. Each publication was examined by two reviewers independently, with differences resolved by consensus. The intra-class correlation coefficient (ICC) was calculated for each outcome of interest to estimate inter-rater reliability. Our outcomes of interest were (1) AI prevalence (the proportion of participants reporting practising AI), (2) monthly frequency of AI and VI, (3) fraction of all intercourse acts and all unprotected intercourse acts which are AI and UAI (details of how these were derived are in Supplement B and C). We extracted participant and study characteristics, including measures of study quality (listed in Table 1, with the addition of alcohol and drug use and sexual and physical violence victimisation). Baseline data only were extracted from longitudinal studies and unadjusted estimates were extracted from studies using respondent-driven sampling. We contacted authors of included studies when key variables of interest were not reported.

\section{Data Synthesis and Statistical Methods}

\section{Prevalence Data}

We produced forest plots of individual study estimates for the most common recall periods. We calculated overall pooled estimates and $95 \%$ confidence intervals $(95 \% \mathrm{CI})$ for AI prevalence across each available recall period. As our review includes diverse populations of FSW, we anticipated substantial heterogeneity in AI prevalence estimates across studies. We therefore pooled results using randomeffects models and conducted extensive sub-group analysis to explore sources of heterogeneity [13-15]. Sub-group analysis on the effect of participant characteristics and study characteristics on pooled AI prevalence estimates were conducted for recall periods with over 10 estimates. Continuous variables were dichotomised at the median. To compare condom use during AI and VI we calculated the proportion reporting any UAI among those reporting AI, as well as the equivalent for VI. We plotted these individual study estimates and produced pooled estimates by recall period (for recall periods with $>3$ estimates). Where studies reported condom use as 'always', 'sometimes' or 'never', rather than over a specific recall period, we define answers other than 
Table 1 Summary of (A) study and participant characteristics and (B) quality of included studies

\begin{tabular}{|c|c|c|}
\hline & $\mathrm{N}=129$ & Sources \\
\hline \multicolumn{3}{|c|}{ (A) Outcomes and key study characteristics } \\
\hline \multicolumn{3}{|c|}{ Outcomes reported ${ }^{\mathrm{a}}$} \\
\hline AI prevalence & 123 & {$[3,9,10,27-34,42,43,45,47-155]$} \\
\hline UAI prevalence only ${ }^{\mathrm{b}}$ & 5 & {$[22-25,156]$} \\
\hline AI frequency & 13 & {$[3,9,10,26,28-36]$} \\
\hline \multicolumn{3}{|l|}{ AI prevalence recall period ${ }^{a}$} \\
\hline Lifetime & 30 & $\begin{array}{l}{[9,28-30,33,42,50,51,54,57,60,63,64,69,79,84,87,100,104,107,120-122,125,126,} \\
\quad 128,130,137,139,141]\end{array}$ \\
\hline 12 Months & 6 & {$[3,42,47,90,105,146]$} \\
\hline 6 Months & 10 & {$[25,75,80,83,86,99,110,114,138,148]$} \\
\hline 3 Months & 7 & {$[22,27,48,58,62,106,144]$} \\
\hline 2 Months & 1 & {$[113]$} \\
\hline 1 Month & 18 & {$[3,9,10,23,28,32,43,45,59,82,85,94,95,98,99,134,143,155]$} \\
\hline 15 days & 1 & {$[65]$} \\
\hline 7 days & 9 & {$[3,43,68,82,108,119,123,127,156]$} \\
\hline 1 day & 1 & {$[67]$} \\
\hline With last client & 1 & {$[154]$} \\
\hline Current primary partner & 3 & {$[29,76,117]$} \\
\hline Not stated & 52 & $\begin{array}{l}{[24,29,31,49,52,53,55,56,61,66,70-74,76-78,81,88,89,91-93,96,97,101-103,109,} \\
\quad 111,112,115-118,124,129,131-133,135,136,140,142,145,147,149-153]\end{array}$ \\
\hline \multicolumn{3}{|l|}{ AI practice reported by partner type ${ }^{\mathrm{a}}$} \\
\hline With any type & 63 & $\begin{array}{l}{[3,9,10,25-28,30,32-36,43,47-52,54-56,58,63,64,66,69,75,77,79,84,90,92,98} \\
100-108,110,113,118,119,122,125,126,128,130,132,134,136,137,139,141-143 \\
146-148,150,152,155]\end{array}$ \\
\hline Clients $^{\mathrm{c}}$ & 62 & $\begin{array}{l}{[22-24,31,42,53,57,59-62,65,67,68,70-74,76,78,80-83,85-89,91,93-97,99,109} \\
\quad 111,112,114-117,120,121,123,124,127,129,131,133,135,138,140,144,145,149 \\
151,153,154,156]\end{array}$ \\
\hline One-time or new clients & 3 & {$[3,29,45]$} \\
\hline Regular clients & 3 & {$[3,29,45]$} \\
\hline Primary or non-paying partner[s) & 15 & {$[3,29,45,76,82,83,87,95,99,117,121,133,144,151,156]$} \\
\hline \multicolumn{3}{|l|}{ Continent $^{\mathrm{a}}$} \\
\hline Africa & 34 & $\begin{array}{l}{[3,10,26-29,34-36,45,48-56,89,104,105,118,119,125,126,130,136,141,146,150,} \\
\quad 153-155]\end{array}$ \\
\hline Asia & 53 & $\begin{array}{l}{[9,10,23,30,33,42,47,57-60,62-65,67-70,72,73,76,83-85,88,90,92,94,95,97,98} \\
\quad 100,102,103,109-116,122-124,132,134,135,140,143,144,147]\end{array}$ \\
\hline Europe & 23 & {$[24,31,32,71,74,77-82,86,93,108,117,120,127,129,133,137,138,145,148]$} \\
\hline South America & 10 & {$[61,66,87,93,101,121,131,139,142,152]$} \\
\hline North America & 14 & {$[22,25,43,75,91,96,99,106,107,128,149,151,156]$} \\
\hline \multicolumn{3}{|l|}{ Mean age $\mathrm{e}^{\mathrm{a}, \mathrm{d}}$} \\
\hline$<28$ years & 71 & $\begin{array}{l}{[3,10,25,26,28,34-36,48-50,53-57,64-69,71-73,75,81-83,85-87,89-91,93,94,96,} \\
\quad 98,100,103-110,112,113,117-119,122,124-126,130-132,134-136,138,140-142,145 \\
146,150,154]\end{array}$ \\
\hline $28+$ years & 57 & $\begin{array}{l}{[9,10,22-25,27,29,31-33,42,43,45,47,48,52,53,58-60,62,63,73,74,76-80,84,88,} \\
\quad 92,93,95,97,99,101,102,111,114-116,121,123,127,128,132,135,137,139,144,147 \\
149,151,153,155,156]\end{array}$ \\
\hline Not stated & 6 & {$[30,51,61,70,120,152]$} \\
\hline \multicolumn{3}{|l|}{ Survey year ${ }^{\mathrm{d}}$} \\
\hline Pre-2003 & 64 & $\begin{array}{l}{[10,26,29,34,35,49,50,52-56,61,66-70,73-82,88,89,91-94,96,101,107,108,113,} \\
\quad 115,117,119,120,122,124,125,128-135,137-139,145,146,148-152]\end{array}$ \\
\hline 2003 onwards & 67 & $\begin{array}{l}{[3,9,22-25,27,28,30-33,36,42,43,45,47,48,51,57-60,62-65,71-73,83-87,90,95} \\
\quad 97-100,102-106,109-112,116,118,121,123,126,127,136,140-144,147,153-156]\end{array}$ \\
\hline \multicolumn{3}{|l|}{ Workplace $^{\mathrm{a}}$} \\
\hline Indoors & 33 & $\begin{array}{l}{[33,52,57,67,69,72,78,80,85,87,92-94,98,102,103,105,108,109,112,113,128,} \\
\quad 130-132,134-137,140,146,147,156]\end{array}$ \\
\hline Outdoors & 12 & {$[10,49,53,56,79,93,108,117,120,127,135,149]$} \\
\hline
\end{tabular}


Table 1 (continued)

\begin{tabular}{|c|c|c|}
\hline & $\mathrm{N}=129$ & Sources \\
\hline Mixed indoors and outdoors & 38 & $\begin{array}{l}{[25,30,35,36,47,50,58-61,63,65,68,71,73,82,86,89,91,96,100,101,110,111,114} \\
\quad 118,121,122,124,126,132,141-143,150,153-155]\end{array}$ \\
\hline Not stated & 53 & $\begin{array}{l}{[3,9,10,22-24,26-29,31,32,34,42,43,45,48,51,54,55,62,64,66,70,74-77,81,83,84,} \\
\quad 88,90,95,97,99,104,106,107,115,116,119,123,125,129,133,138,139,144,145,148, \\
151,152]\end{array}$ \\
\hline \multicolumn{3}{|c|}{ Mean number of clients per week ${ }^{\mathrm{a}, \mathrm{d}}$} \\
\hline$<10$ & 45 & $\begin{array}{l}{[9,25,27,29,35,36,42,47,48,54,57,60,65,81,83-85,89,90,94,96,97,99,100,104} \\
\quad 109,112-116,119,121-124,126,128,129,140,141,146,148,151,156]\end{array}$ \\
\hline $10+$ & 46 & $\begin{array}{l}{[3,10,25,26,31,33,34,45,49,50,52,53,55,56,58,59,61-63,66-69,71,74,77,78,80,} \\
\quad 85,86,92,102,103,108,127,132-135,137,139,142,147,149,152,153]\end{array}$ \\
\hline Not stated & 40 & $\begin{array}{l}{[10,22-24,28,30,32,43,51,53,64,70,72,73,75,76,79,87,88,91,93,95,98,101} \\
\quad 105-107,110,111,117,118,120,125,129,136,138,143,144,150,154,155]\end{array}$ \\
\hline \multicolumn{3}{|c|}{ (B) Study quality and potential for bias } \\
\hline \multicolumn{3}{|l|}{ Interview method ${ }^{\mathrm{a}}$} \\
\hline ACASI & 10 & {$[22,27,28,42,83,86,106,107,144,155]$} \\
\hline SAQ & 5 & {$[31,91,112,133,145]$} \\
\hline SAQ or FTFI ${ }^{\mathrm{e}}$ & 2 & {$[73,81]$} \\
\hline FTFI & 111 & $\begin{array}{l}{[3,9,23-27,29,30,32-34,36,45,47-72,74-80,82,84,85,87-90,92-105,108-111} \\
\quad 113-132,134-143,153,154,156]\end{array}$ \\
\hline Coital diary & 4 & {$[10,26,35,43]$} \\
\hline Polling box & 1 & [23] \\
\hline \multicolumn{3}{|l|}{ Study design } \\
\hline Cross-sectional & 116 & $\begin{array}{l}{[3,9,22-24,26-32,34-36,42,43,47,48,50,51,53-63,65-68,70-74,76-86,89-91} \\
\quad 93-118,120-128,130-137,139-145,153-156]\end{array}$ \\
\hline Cohort $^{\mathrm{f}}$ & 11 & {$[25,33,45,49,64,69,75,88,119,129,138]$} \\
\hline Randomised-controlled trial ${ }^{\mathrm{f}}$ & 4 & {$[10,52,87,92]$} \\
\hline \multicolumn{3}{|l|}{ Sampling method } \\
\hline Convenience & 96 & $\begin{array}{l}{[10,22,24-27,31,32,34-36,43,45,48-51,53-56,58,60,62,65-69,74-82,88,89,91-94} \\
\quad 96-103,106,108,110-135,137-139,142-145,154-156]\end{array}$ \\
\hline Simple-randomised sampling & 5 & {$[29,70,87,132,136]$} \\
\hline Cluster-randomised sampling & 7 & {$[9,57,72,84,85,107,109]$} \\
\hline Respondent-driven sampling & 19 & {$[3,23,28,42,52,59,61,64,71,73,83,86,90,95,104,105,140,141,153]$} \\
\hline Time-location sampling & 4 & {$[30,33,47,63]$} \\
\hline \multicolumn{3}{|l|}{ Response rate } \\
\hline$<90 \%$ & 9 & {$[29,62,67,71,93,98,112,114,121]$} \\
\hline $90 \%+$ & 12 & {$[9,58,63,92,94,101,110,111,115,118,126,144]$} \\
\hline Not stated & 110 & $\begin{array}{l}{[3,10,22-25,27,28,31,32,34-36,42,43,45,47-51,53-56,66,68-70,77-84,88-90} \\
\quad 94-97,99-105,107-109,113,116,117,119,120,122-125,128-143,145-153,155-157]\end{array}$ \\
\hline \multicolumn{3}{|c|}{ Place in paper where $\mathrm{AI}$ is first mentioned } \\
\hline Title & 11 & {$[3,9,22,29,45,47,48,51,53,83,84]$} \\
\hline Abstract & 32 & {$[25-28,30,33,52,57-65,67,71-76,85-87,91,98,106,127,130,154]$} \\
\hline Text & 88 & $\begin{array}{l}{[10,23,24,31,32,34-36,42,43,49,50,54-56,66,68-70,77-82,88-90,92-97,99-105} \\
\quad 107-126,128,129,131-153,155,156]\end{array}$ \\
\hline
\end{tabular}

$A I$ anal intercourse, $U A I$ unprotected anal intercourse, ACASI audio-computer assisted self-interview, FTFI face-to-face interview, SAQ selfadministered questionnaire

${ }^{\mathrm{a}}$ The sum is greater than the total number of included studies because several studies provided AI data in more than one category

${ }^{\mathrm{b}}$ Studies which reported AI prevalence for unprotected AI only

${ }^{\mathrm{c}}$ Not specified whether one-off or regular

${ }^{\mathrm{d}}$ Numerical variables were dichotomised at the median

${ }^{\mathrm{e}}$ Depending on participant preference/ability

${ }^{\mathrm{f}}$ Baseline data only extracted 
'always' as practising UAI or UVI and refer to this recall period as general condom use. All models were fitted using maximum-likelihood random-effects models $[16,17]$ with the procedure 'Metafor' [18] in R version 3.20.1 [19]. Heterogeneity across study estimates was investigated using Cochran's Q test and its $p$ value [20] as well as $\mathrm{I}^{2}$ estimates [21].

\section{Frequency Data}

To enable comparison across studies which reported number of AI acts by different recall periods, we standardised frequency estimates to number of acts per month. Where possible, we derived the proportion of all intercourse acts that were AI or UAI. When the mean number of AI acts was reported only among the sub-samples who practise AI, we also derived the mean among the whole sample, when AI prevalence was also reported. As very few studies reported measures of variance of intercourse act data, we were unable to conduct statistical synthesis of frequency data; thus, we limited our analysis to graphically exploring the effects of participant and study characteristics on the proportion of intercourse acts that were anal.

\section{Dealing with Bias}

Our sub-group analyses included exploring the effect of different measures of methodological quality; interview method, study design, recruitment method and response rate. We also examined through sub-group analysis the section in the article where AI was first mentioned (title, abstract or main text), which we used to explore the possible effect of publication bias as authors may be more likely to include or highlight AI data when the practice is more common.

\section{Results}

\section{Search Results}

Figure S1 summarises the study selection procedure and search results. Of the 13,658 unique articles initially identified, 131 were included. Most articles were identified from the database searches, and two were identified through reference scanning. Additional information was obtained from 23 of the 35 authors contacted. Inter-rater reliability for the outcomes of interest was high, with ICC ranging from 0.85 for $\mathrm{AI}$ frequency data to 0.96 for $\mathrm{AI}$ prevalence data.

\section{Study and Participant Characteristics}

Details of each included study are presented in Table SI and participant and study characteristics are summarised in Table 1. AI prevalence was reported over various recall periods by 128 studies (including five studies reporting UAI prevalence only [22-25] with five comparing AI prevalence over two or more recall periods [3, 9, 29-31]. The most common AI prevalence recall periods were lifetime $(\mathrm{N}=30)$ and 1 month $(\mathrm{N}=18)$. A very large number of studies failed to state the recall period at all $(\mathrm{N}=52)$; these included 35 studies which reported whether FSW provided AI as part of their service. AI frequency data (either number of AI acts and/or the proportion of intercourse acts which were AI) was provided by only 13 studies.

Sample sizes ranged from 12 to 9667 for a total sample size of 74,426 across all studies (Table SI). Nearly half of the studies specified partner type, with 15 reporting AI practice separately for non-paying partners and paying clients. Most studies were conducted in Asia $(\mathrm{N}=53)$, followed by Africa $(\mathrm{N}=34)$ and Europe $(\mathrm{N}=23)$, with few conducted in the Americas ( $\mathrm{N}=14$ in North, $\mathrm{N}=10$ in South America, respectively). Median age across studies was 28 years and median survey year 2003. The vast majority of studies either did not report location of work $(\mathrm{N}=53)$ or reported on samples with a mixture of indoor and outdoor sex workers $(\mathrm{N}=38)$.

We were unable to include the use of alcohol (reported by 23 studies, or drug use (reported by 20 studies) or physical and sexual violence (reported by 12 and 11 studies, respectively) in our analysis, because they were too rarely reported and when reported, used a wide range of recall periods.

\section{Study Quality and Potential Bias}

More studies reported on FSW who worked only indoors $(\mathrm{N}=33)$, than outdoors $(\mathrm{N}=12)$ (Table 1). Most studies used face-to-face interviews (FTFI) $(\mathrm{N}=111)$, were crosssectional in design $(\mathrm{N}=116)$ and employed convenience sampling $(\mathrm{N}=96)$. Three studies compared the reporting of AI practice by interview method [23, 26, 27]. Most failed to report the response rate $(\mathrm{N}=110)$. More studies first mentioned $\mathrm{AI}$ in the main text $(\mathrm{N}=88)$, than abstract $(\mathrm{N}=32)$ or title $(\mathrm{N}=11)$ (Table 1).

\section{Meta-analysis of AI Prevalence}

Figure 1 displays pooled estimates of AI prevalence for all recall periods and Fig. S2a-c displays individual study estimates for the three most common recall periods (lifetime and past month), respectively. Reported AI 
Fig. 1 Pooled estimates of the prevalence of anal intercourse over each recall period reported. $A I$ anal intercourse, $N A$ not applicable, 95\% CI 95\% confidence interval. The top of each diamond represents the pooled estimate, while furthest points represent $95 \% \mathrm{CI}$. $\mathrm{I}^{2}$ and Q Test are both measures of heterogeneity, with higher values in both indicating greater heterogeneity. $\mathrm{I}^{2}$ ranges from $0-100 \%$. The results of the Q Test are displayed in bold when the $p$-value is $<0.05$, which indicates that the level of heterogeneity found is statistically significant

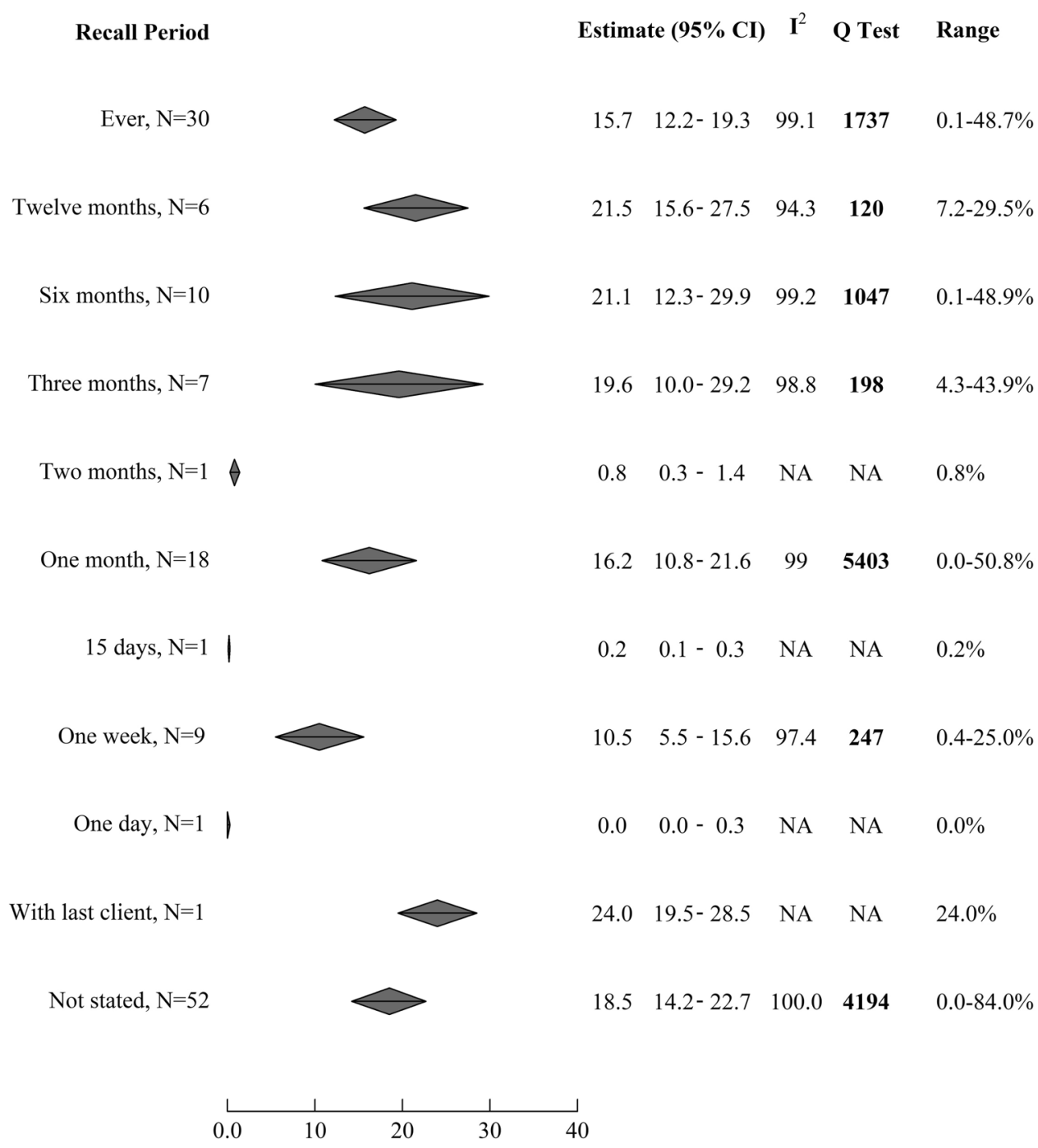

Pooled estimates of anal intercourse prevalence by recall period (\%) prevalence varied substantially between studies, ranging from 0.0 to $84.0 \%$ across recall periods (Table S1). Estimates stratified by recall period remained very heterogeneous $\left(\mathrm{I}^{2}>90 \%\right.$ and all $\mathrm{Q}$ tests showing statistically significant heterogeneity). Pooled AI prevalence did not vary substantially by length of recall period apart from 2 months, 15 days and 1 day recall periods, which all only had one study each (Fig. 1). Aside from these, pooled estimates varied between $10.5 \%$ (95\% CI $5.5-15.6 \%, \mathrm{~N}=8)$ in the past week and $21.5 \%(95 \% \mathrm{CI}$ $15.6-27.5 \%, \mathrm{~N}=6$ ) in the past year, and the pooled estimate for reporting ever having practiced AI was $15.7 \%$ (95\%CI12.2-19.3).

\section{Sub-group Analysis of AI Prevalence}

Table 2 shows pooled estimates from sub-group analyses of AI prevalence by participant and study characteristics for recall periods with sufficient numbers of study estimates (ever and past 1 month).

\section{Participant Characteristics}

Pooled estimates of lifetime AI practice tended to be higher among older FSW $[28+$ years $=20.7 \%$ (95\% CI 14.5-26.9\%, $\mathrm{N}=13)$ vs. $<28$ years $=11.9 \%(95 \%$ CI $7.9-15.9 \%, \mathrm{~N}=14)$, in studies conducted after 2002 (2003 onwards $=19.2 \%$ $(95 \%$ CI $15.4-24.8 \%, \mathrm{~N}=18)$ vs pre-2003 $=12.9 \%(95 \% \mathrm{CI}$ $5.3-19.2 \%, \mathrm{~N}=13)$. The same patterns were seen for AI practice in the past month, but as with lifetime prevalence, differences between sub-groups were not significant. Pooled 
Table 2 Sub-group analysis of AI prevalence over the most common recall periods, by participant and study characteristics

\begin{tabular}{|c|c|c|c|c|c|c|c|c|}
\hline \multirow[t]{2}{*}{ Study characteristics } & \multicolumn{4}{|c|}{ Ever } & \multicolumn{4}{|c|}{ Past month } \\
\hline & $\mathrm{N}$ & \multicolumn{2}{|c|}{$\begin{array}{l}\text { Pooled estimate (95\% } \\
\text { CI) }\end{array}$} & \multirow[t]{2}{*}{$\mathrm{I}^{2}$} & \multirow[t]{2}{*}{$\mathrm{N}$} & \multicolumn{2}{|c|}{$\begin{array}{l}\text { Pooled estimate (95\% } \\
\text { CI) }\end{array}$} & \multirow[t]{2}{*}{$\mathrm{I}^{2}$} \\
\hline \multicolumn{6}{|c|}{ Participant characteristics } & & & \\
\hline \multicolumn{9}{|c|}{ Partner type } \\
\hline Any & 25 & $14.8 \%$ & $(11.0-18.6)$ & 99 & 15 & $15.1 \%$ & $(8.8-21.6)$ & 99 \\
\hline Clients & 6 & $19.7 \%$ & $(11.3-28.0)$ & 97 & 6 & $24.0 \%$ & $(13.9-34.1)$ & 99 \\
\hline New clients & 0 & - & - & - & 2 & $20.3 \%$ & $(8.7-32.0)$ & 90 \\
\hline Regular clients & 0 & - & - & - & 2 & $24.8 \%$ & $(10.0-39.5)$ & 94 \\
\hline Non-paying partners & 2 & $43.9 \%$ & $(14.7-73.1)$ & 97 & 5 & $16.5 \%$ & $(11.4-21.6)$ & 83 \\
\hline \multicolumn{9}{|l|}{ Continent } \\
\hline Africa & 10 & $15.1 \%$ & $(8.8-21.4)$ & 98 & 7 & $20.4 \%$ & $(10.1-31.8)$ & 98 \\
\hline Asia & 13 & $14.5 \%$ & $(10.2-18.8)$ & 99 & 12 & $14.0 \%$ & $(6.3-21.6)$ & 99 \\
\hline Europe & 3 & $8.0 \%$ & $(1.9-14.0)$ & 86 & 2 & $21.4 \%$ & $(12.9-29.8)$ & 64 \\
\hline South America & 3 & $22.2 \%$ & $(14.3-30.2)$ & 82 & 0 & - & - & - \\
\hline North America & 2 & $29.1 \%$ & $(1.8-56.3)$ & 95 & 2 & $18.4 \%$ & $(10.4-26.4)$ & 0 \\
\hline \multicolumn{9}{|l|}{ Mean age } \\
\hline$<28$ years & 14 & $11.9 \%$ & $(7.9-15.9)$ & 98 & 10 & $15.5 \%$ & $(5.4-25.6)$ & 99 \\
\hline $28+$ years & 13 & $20.7 \%$ & $(14.5-26.9)$ & 99 & 12 & $18.3 \%$ & $(13.2-24.0)$ & 95 \\
\hline Not stated & 4 & $10.8 \%$ & $(4.3-17.3)$ & 98 & 1 & $11.4 \%$ & $(7.1-15.7)$ & - \\
\hline \multicolumn{9}{|l|}{ Survey year } \\
\hline Pre-2003 & 13 & $12.9 \%$ & $(5.3-19.2)$ & 99 & 7 & $10.5 \%$ & $(1.0-19.9)$ & 99 \\
\hline 2003 onwards & 18 & $19.2 \%$ & (15.4-24.8) & 98 & 16 & $19.4 \%$ & $(13.2-26.0)$ & 98 \\
\hline \multicolumn{9}{|l|}{ Workplace } \\
\hline Indoors & 7 & $21.4 \%$ & $(12.2-30.5)$ & 94 & 5 & $14.4 \%$ & $(0.0-33.8)$ & 99 \\
\hline Outdoors & 2 & $5.5 \%$ & $(0.0-11.7)$ & 86 & 1 & $40.6 \%$ & $(33.6-47.7)$ & - \\
\hline Mixed & 10 & $8.8 \%$ & $(4.8-12.8)$ & 98 & 4 & $13.3 \%$ & $(11.1-16.1)$ & 1 \\
\hline Not stated & 12 & $20.0 \%$ & $(15.7-24.3)$ & 97 & 13 & $16.8 \%$ & (11.6-22.0) & 96 \\
\hline \multicolumn{9}{|l|}{ Number of clients/week } \\
\hline$<8$ & 12 & $18.6 \%$ & $(10.5-26.7)$ & 99 & 5 & $13.6 \%$ & $(7.1-20.0)$ & 97 \\
\hline $8+$ & 9 & $13.5 \%$ & $(10.6-16.5)$ & 84 & 10 & $19.6 \%$ & $(9.3-29.9)$ & 99 \\
\hline Not stated & 10 & $14.3 \%$ & $(9.8-18.8)$ & 97 & 8 & $15.2 \%$ & $(9.0-21.5)$ & 96 \\
\hline \multicolumn{9}{|c|}{ Study quality and potential for bias } \\
\hline \multicolumn{9}{|l|}{ Interview method } \\
\hline ACASI & 3 & $19.3 \%$ & $(9.8-28.7)$ & 95 & 2 & $11.3 \%$ & $(2.7-16.3)$ & 98 \\
\hline SAQ & 0 & - & - & - & 0 & - & - & - \\
\hline FTFI & 28 & $15.4 \%$ & $(11.6-19.1)$ & 99 & 15 & $17.0 \%$ & $(10.3-23.6)$ & 99 \\
\hline SAQ/FTFI & 0 & - & - & - & 0 & - & - & - \\
\hline Coital diary & 0 & - & - & - & 5 & $15.4 \%$ & $(2.9-27.9)$ & 97 \\
\hline Polling box & 0 & - & - & - & 1 & $26.0 \%$ & $(20.8-31.3)$ & NA \\
\hline \multicolumn{9}{|l|}{ Study design } \\
\hline Cross-sectional & 26 & 15.4 & $(11.4-19.4)$ & 99 & 14 & $17.5 \%$ & $(11.4-23.5)$ & 99 \\
\hline Cohort & 3 & 15.0 & $(10.3-19.8)$ & 57 & 1 & $37.0 \%$ & $(30.3-43.7)$ & NA \\
\hline RCT & 1 & 31.9 & $(23.6-40.3)$ & NA & 1 & $14.1 \%$ & $(11.7-16.6)$ & NA \\
\hline \multicolumn{9}{|l|}{ Recruitment method } \\
\hline Convenience & 16 & $13.2 \%$ & $(8.3-18.1)$ & 98 & 16 & $13.9 \%$ & $(7.3-21.3)$ & 99 \\
\hline Simple randomised & 2 & $36.4 \%$ & $(30.2-42.5)$ & 12 & 0 & - & - & - \\
\hline Cluster randomised & 5 & $14.8 \%$ & $(10.9-18.9)$ & 96 & 3 & $26.9 \%$ & $(7.8-46.1)$ & 99 \\
\hline Respondent-driven & 5 & $17.8 \%$ & $(9.9-25.6)$ & 96 & 6 & $17.1 \%$ & $(12.5-21.7)$ & 90 \\
\hline Time-location & 3 & $13.7 \%$ & $(10.2-17.2)$ & 90 & 0 & - & - & - \\
\hline
\end{tabular}


Table 2 (continued)

\begin{tabular}{|c|c|c|c|c|c|c|c|c|}
\hline \multirow[t]{2}{*}{ Study characteristics } & \multicolumn{4}{|c|}{ Ever } & \multicolumn{4}{|c|}{ Past month } \\
\hline & $\mathrm{N}$ & \multicolumn{2}{|c|}{$\begin{array}{l}\text { Pooled estimate (95\% } \\
\text { CI) }\end{array}$} & $\mathrm{I}^{2}$ & $\mathrm{~N}$ & \multicolumn{2}{|c|}{$\begin{array}{l}\text { Pooled estimate (95\% } \\
\text { CI) }\end{array}$} & $I^{2}$ \\
\hline \multicolumn{9}{|l|}{ Response rate } \\
\hline$<90 \%$ & 2 & $18.9 \%$ & $(8.3-29.5)$ & 99 & 1 & $10.2 \%$ & $(7.0-14.4)$ & NA \\
\hline $90+$ & 3 & $12.9 \%$ & $(4.1-21.8)$ & 99 & 1 & $13.3 \%$ & $(10.5-16.2)$ & NA \\
\hline Not stated & 25 & $15.3 \%$ & $(11.6-19.1)$ & 99 & 16 & $16.6 \%$ & $(13.5-25.8)$ & 99 \\
\hline \multicolumn{9}{|l|}{ AI first mentioned } \\
\hline Title & 4 & $23.9 \%$ & $(14.0-33.8)$ & 97 & 3 & $23.8 \%$ & $(12.8-34.7)$ & 95 \\
\hline Abstract & 10 & $16.9 \%$ & $(13.4-20.5)$ & 95 & 5 & $20.1 \%$ & $(6.0-34.2)$ & 99 \\
\hline Text & 17 & $13.2 \%$ & $(8.0-18.3)$ & 99 & 15 & $14.1 \%$ & $(8.1-20.2)$ & 99 \\
\hline
\end{tabular}

$\mathrm{I}^{2}$ is a measure of heterogeneity which can lie between $0 \%$ and $100 \%$; with higher percentages indicating greater heterogeneity

Studies provided one estimate of AI prevalence with the following exceptions: Among studies reporting lifetime AI prevalence Kinsler et al. and Hakre et al. [87, 121] provided estimates by partner type. Among studies reporting one month AI prevalence Priddy et al., Kazerooni et al., Ojeda et al. and Maheu et al. [3, $45,95,99$ ] provided estimates by partner type and Hanck et al. [23]. by interview method. Multiple study estimates per study were used only when the estimates belonged to different categories e.g. if AI prevalence estimates were available with clients and non-paying partners, then both were included in the partner type sub-group analysis, otherwise only the single estimate with the highest denominator was used

$A I$ anal intercourse, ACASI audio-computer assisted self-interview, FTFI face-to-face interview, $S A Q$ selfadministered questionnaire, $95 \%$ CI 95\% confidence interval

estimates did not vary by partner type, continent, average number of clients or location of work.

\section{Study Quality and Bias}

Pooled estimates of lifetime and past month prevalence for cross-sectional studies were lower compared to estimates from RCT and cohort studies, respectively. However, these observations are inconclusive as there was only one RCT and one cohort study reported lifetime and past month prevalence, respectively. Pooled estimates of lifetime and 1 month AI practice was higher when the word 'anal' was first mentioned in the article title compared to in the abstract or main text [e.g. for lifetime, title $=23.9 \%$ (95\% CI 14.0-33.8\%, $\mathrm{N}=4)$ versus text $=13.2 \%(95 \% \mathrm{CI} 8.0-18.3 \%, \mathrm{~N}=17)]$. Pooled estimates did not vary by interview method, recruitment method or response rate.

\section{Comparative Condom use During Al and VI}

Pooled estimates of the prevalence of UAI among those reporting AI were higher than UVI among those reporting VI in four of the five recall periods over which it was reported (Fig. 2) [e.g. general UAI $=46.0 \%(95 \% \mathrm{CI}$ 30.8-61.3), UVI $=31.6 \%$ (95\%CI 18.7-44.5)], although 95\%CIs overlapped substantially (individual study estimates are plotted in Fig. S3a-d).

\section{Frequency of Al Compared to VI}

Of the 13 studies which provided data on the number of AI acts, we were able to extract or derive eight estimates among the subset of FSW who report practising AI [3, 9, 10, 28-32] and eight over the whole sample [3, 10, 26, 32-36], which includes FSWs not practising AI (Table 3). AI frequency estimates vary substantially across studies. Across the studies providing data among the subset of FSWs reporting AI, the number of $\mathrm{AI}$ and UAI acts per month ranged from 1.8 to $27.8(\mathrm{~N}=8)$ and from 0.2 to $6.2(\mathrm{~N}=3)$, respectively. Among studies reporting mean frequency across the whole study sample, the total number of AI and UAI acts ranged from 1.1 to $16.9(\mathrm{~N}=8)$ and 1.0 to $1.7(\mathrm{~N}=3)$. The percentage of all intercourse acts that were anal ranged from 2.4 to $15.9 \%$ in the six studies that reported it across the whole sample [3, 26, 33-36]. In the sole study which reported it among the subset practising AI [3], 17.0\% of intercourse acts were anal. The proportion of intercourse acts that were anal did not vary substantially by any participant or study characteristics (Fig. 3).

\section{Discussion}

This extensive review adds to the current literature and understanding of AI practices among FSW. We found that reported AI practice is generally common among FSW worldwide, with a pooled estimate of $15.7 \%$ (95\% CI 


\section{Recall Period}

At last sex

UVI, $\mathrm{N}=6$

UAI, $\mathrm{N}=9$

One week

UVI, N=5

UAI, $\mathrm{N}=5$

One month

UVI, N=3

UAI, $\mathrm{N}=6$
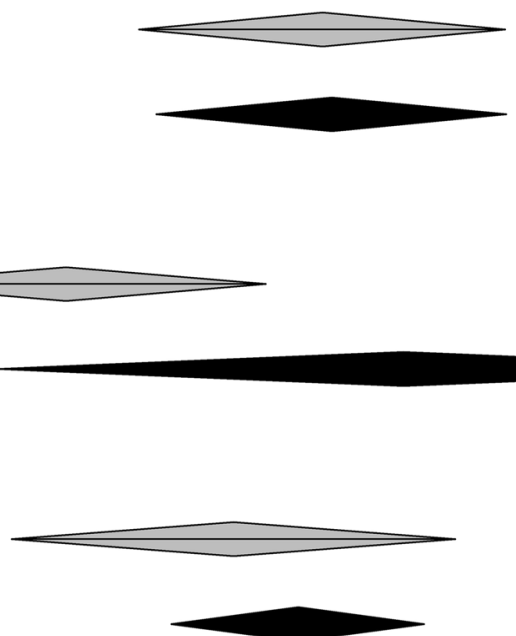

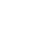

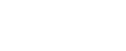

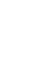

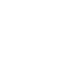

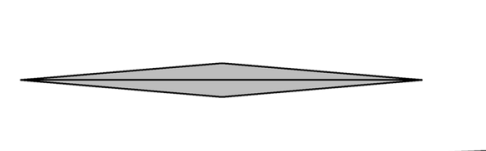

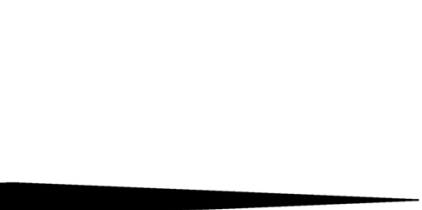

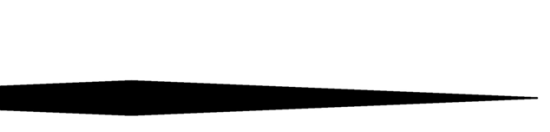

$19.1 \quad 1.7-36.4$

$99 \quad \mathbf{1 6 5}$

$48.3 \quad 13.2-83.4$

$97 \quad 209$

General

UVI, $\mathrm{N}=12$

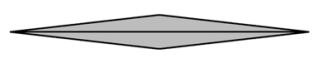

$31.6 \quad 18.7-44.5$

$99 \quad 936$

UAI, $\mathrm{N}=15$

$46.0 \quad 31-61.3$

$99 \quad \mathbf{2 5 0}$

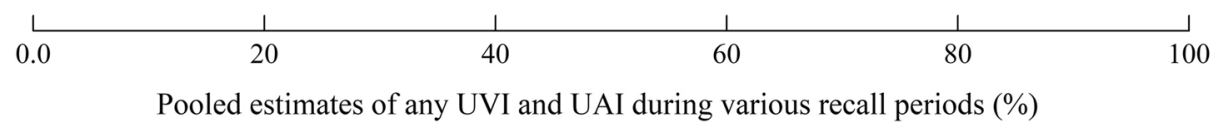

Fig. 2 Pooled estimates of the prevalence of anal intercourse and vaginal intercourse unprotected by condoms, by recall period. Pooled estimates of the proportion of those who report any AI unprotected by condoms among those reporting any AI over the most commonly reported recall periods, and the equivalent pooled estimates for UVI.

12.2-19.3) ever having practised AI. There was substantial heterogeneity across study estimates that largely was not explained by any of the measured participant and study characteristics. AI tended to be more often unprotected by condoms compared to VI, although this was not statistically significantly different. Although scarce, the available data on $\mathrm{AI}$ frequency suggests that $\mathrm{AI}$ is practised frequently, with $2.4-15.9 \%$ of all intercourse acts being anal among all FSW study participant samples.

Similar to previous review findings regarding heterosexual AI practice among young people and South Africans [37, 38], we found a non-statistically significant indication that AI prevalence may have increased over time. In qualitative research Indian and East African FSW have described AI practice during sex work as becoming more common over time due to increased client demand [9, 39-41]. Pooled AI prevalence varied little across recall periods and in the four
$U A I$ anal intercourse unprotected by condoms, $U V I$ vaginal intercourse unprotected by condoms, 95\% CI 95\% confidence interval, general report that condom use is anything other than 'always' using condoms

studies which reported AI practice over multiple recall periods AI prevalence changed little as recall periods lengthened $[3,28,42,43]$. These findings suggest that those who initiate AI continue to practise it.

The strengths of our study include conducting a wide search and identifying a large number of eligible studies, resulting in a large sample size. Our review was greatly strengthened by using wide search terms, for example, omitting the word 'anal', ensured that we captured eligible studies which first mentioned $\mathrm{AI}$ in the main text, rather than the title or abstract. Given that AI prevalence tended to be lower the later in the article that AI was first mentioned, our search strategy limited the impact of publication bias, thus increasing the accuracy of our results. Deriving estimates for AI practice where possible also helped reduce publication bias. We conducted a detailed sub-group analysis to identify potential sources of heterogeneity in AI practice based on 


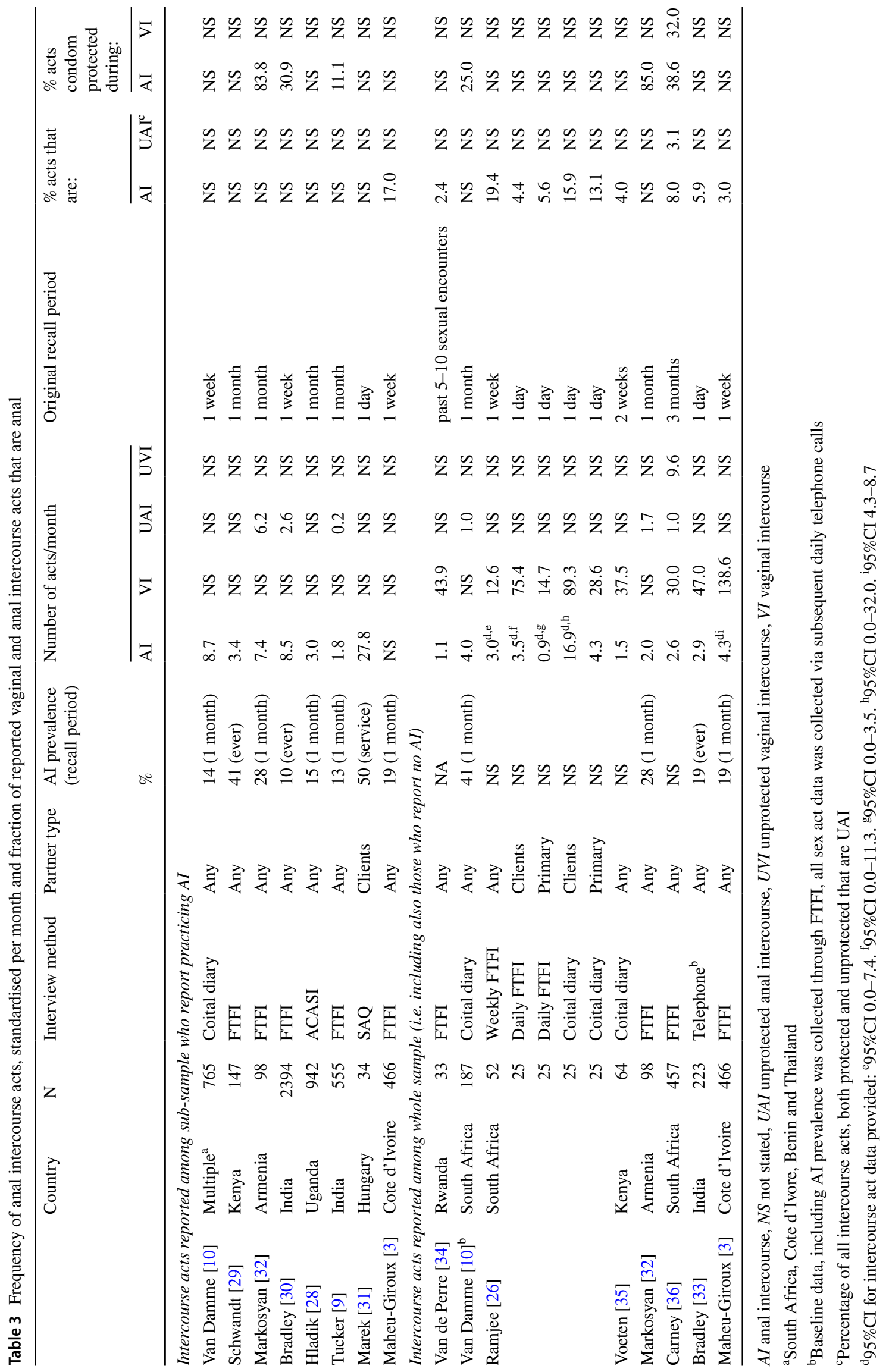



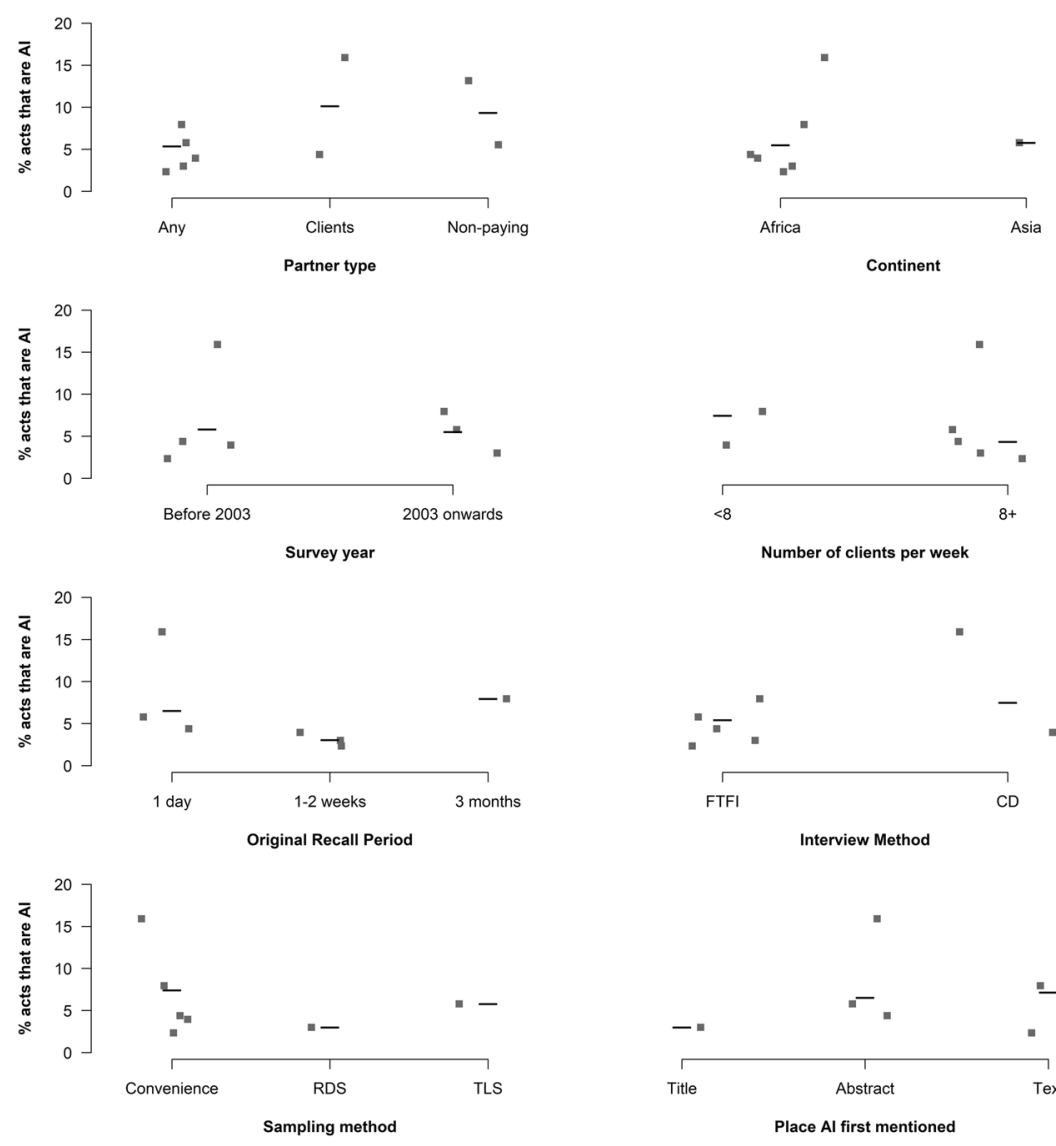

Fig. 3 Proportion of intercourse acts that are anal by selected study and participant characteristics Scatter plots of the proportion of intercourse acts that are anal among the whole sample (i.e. including those reporting no AI) participant characteristics and study characteristics. $A C A S I$ audio computer assisted self-interview, $C D$ coital diary, $C R S$

characteristics measured in the study, including measures of study quality.

Our review has a number of limitations. We did not include articles in languages other than English, or grey literature, which may have resulted in omission of potentially eligible articles. Our language restriction resulted in the exclusion of 42 potentially eligible full-text articles. Eleven percent full-text articles examined were found to be eligible, and if the same proportion of identified non-English fulltext articles were eligible, this would have resulted in the inclusion of an additional four or five studies to our review. However, the language restriction is unlikely to have influenced results substantially given the large number of articles included $(\mathrm{N}=131)$. We searched for grey literature in our similar review of heterosexual AI among South Africans [37] and found none eligible.

Our review was mainly limited by the quality of reporting on $\mathrm{AI}$ practice. Of the 131 included studies, 52 failed to report the recall period of AI prevalence. Only a third of studies reporting AI prevalence also provided data on cluster-randomised sampling, FTFI face-to-face interview, Mix data only available for men and women combined, $N S$ not stated, $R C T$ randomised controlled trial, $R D S$ respondent-driven sampling, $S A Q$ selfadministered questionnaire, SRS simple randomised sampling, TLS Time-location sampling

condom use during AI as well as VI. Only 10\% (13 of 131 studies) of included studies reported any type of AI frequency data, and a single study provided the number of each type of intercourse act necessary to fully describe AI frequency (number of anal and vaginal acts over the same recall period, both condom protected and not) [36]. Only two studies $[3,26]$ provided standard deviation or $95 \% \mathrm{CI}$ for intercourse act data, which prevented us from pooling the few data available.

$\mathrm{AI}$ is a highly stigmatised behaviour in many societies and thus its reporting is likely subject to social desirability bias and is likely more accurately reported using more confidential interview methods $[37,38]$. As the majority of studies in this review used FTFI, the least confidential interviewing method, our pooled estimates of AI prevalence and estimates of AI frequency likely underestimate its practice among FSW. Our sub-group analysis found that AI prevalence was not higher in the small number of studies which used more confidential methods compared to those that used FTFI. However, the two included studies which compared AI 
prevalence by interview method both found non-significantly higher prevalence using more confidential methods compared to FTFI [23, 27]. One study in this review compared $\mathrm{AI}$ frequency by interview method, finding more than five times as many anal intercourse acts were reported by FSW in South Africa when using coital diaries compared to daily FTFI [26].

\section{Recommendations for Future Reporting of Al Practice}

It is clear from this review and others $[37,38]$ that data collection on AI practice requires improvement, especially given how effectively HIV is transmitted during AI and how commonly it is practiced. Previous research suggests that survey items must be carefully piloted in order to minimise misunderstanding and that one effective approach may be the use of pictograms to unambiguously clarify what is meant by AI [44]. Using confidential interview methods would help reduce social-desirability bias.

We need data that paints a complete picture of AI practice and which allows the proportion of all intercourse acts that are anal to be estimated. Accurately estimating this proportion is key to estimating the extent to which AI impacts on HIV epidemics among FSW [4]. In order to minimise bias when estimating the fraction of intercourse acts that are AI, the same recall period should be used to collect data on AI and VI practice. We recommend that the following questions be included in all surveys on sexual behaviour among FSW:

- Have you had AI in the past 12 months?

- How many VI acts have you had in the past week with (a) clients and (b) non-paying partners?

- Was a condom used throughout your last VI act with (a) a client and (b) a non-paying partner

- How many AI acts have you had in the past week with (a) clients and (b) non-paying partners?

- Was a condom used throughout your last AI act with (a) a client and (b) a non-paying partner

These recall periods may not be suitable for all FSW populations. In the case of low client volume, for example, we recommend collecting data on the number of intercourse acts over the past month. Equivalent questions should also be included in surveys among general population men and women, although past month may be a more suitable recall period for intercourse act data.

\section{Public Health Implications}

This review provides valuable information that can be used to guide policy, research and survey design internationally, as well as to inform future mathematical models of HIV epidemics among FSW and to predict the influence that AI practice may have on intervention effectiveness. Our review has found that, while varied, AI is commonly and frequently practised by FSW, and that condoms are often less consistently used during AI compared to VI. As such, AI may substantially contribute to HIV epidemics among FSW and their sexual partners. Messaging on safe AI practice is often absent from current interventions among FSW, but should be included [39, 45, 46]. As practice of AI by FSW is most often driven by client demand [9, 39, 40, 47], programmes should address the social and environmental factors which contribute to vulnerability and hinder negotiation of safe practice; as well as target clients with safe AI messages.

Author's Contributions BNO conducted the search from 1990 onwards, extracted data, conducted analysis and prepared the manuscript. JE conducted the search from 1980 to 1989. AH, ZS, ARB and JE checked data extraction. RS, PA, BS, AvdS contributed to the manuscript. MCB and RFB conceptualized and supervised the review. All authors read and approved the final draft.

Funding Research reported in this publication was supported by the National Institute of Allergy and Infectious Diseases of the National Institutes of Health [Grant Number R01AI057020]. The content is solely the responsibility of the authors and does not necessarily represent the official views of the National Institutes of Health. BNO's work was supported by a studentship from the AMS, Austria.

\section{Compliance with Ethical Standards}

Conflict of interest We declare that there are no conflict of interest.

Ethical Approval This article does not contain any studies with human participants or an performed by any of the authors.

Open Access This article is distributed under the terms of the Creative Commons Attribution 4.0 International License (http://creativeco mmons.org/licenses/by/4.0/), which permits unrestricted use, distribution, and reproduction in any medium, provided you give appropriate credit to the original author(s) and the source, provide a link to the Creative Commons license, and indicate if changes were made.

\section{References}

1. Baggaley RF, White RG, Boily M-C. HIV transmission risk through anal intercourse: systematic review, meta-analysis and implications for HIV prevention. Int $\mathrm{J}$ Epidemiol. 2010;39(4):1048-63.

2. Boily MC. The relative contribution of anal intercourse and primary infection to mature heterosexual HIV epidemics. Sex Transm Infect. 2011;87(Suppl 1):A38 (Abstract 01-S07.01).

3. Maheu-Giroux M, Baral S, Vesga JF, Diouf D, Diabaté S, Alary $\mathrm{M}$, et al. Anal intercourse among female sex workers in cote d'ivoire: prevalence, determinants, and model-based estimates 
of the population-level impact on HIV transmission. Am J Epidemiol. 2017;187(2):287-97.

4. Baggaley RF, Dimitrov D, Owen BN, Pickles M, Butler AR, Masse B, et al. Heterosexual anal intercourse: a neglected risk factor for HIV? Am J Reprod Immunol. 2013;69(Suppl 1):95-105.

5. Chow EPF, Muessig KE, Yuan L, Wang Y, Zhang X, Zhao R, et al. Risk Behaviours among female sex workers in China: a systematic review and data synthesis. Operario D, editor. PLoS ONE. 2015;10(3):e0120595.

6. Toska E, Pantelic M, Meinck F, Keck K, Haghighat R, Cluver L. Sex in the shadow of HIV: a systematic review of prevalence, risk factors, and interventions to reduce sexual risk-taking among HIV-positive adolescents and youth in sub-Saharan Africa. PLoS ONE. 2017;12(6):e0178106.

7. Awungafac G, Delvaux T, Vuylsteke B. Systematic review of sex work interventions in sub-Saharan Africa: examining combination prevention approaches. Trop Med Int Health. 2017;22(8):971-93.

8. Chersich MF, Luchters S, Ntaganira I, Gerbase A, Lo Y-R, Scorgie $\mathrm{F}$, et al. Priority interventions to reduce HIV transmission in sex work settings in sub-Saharan Africa and delivery of these services. JIAS. 2013;16:17980.

9. Tucker S, Krishna R, Prabhakar P, Panyam SAP. Exploring dynamics of anal sex among female sex workers in Andhra Pradesh. Indian J Sex Transm Dis. 2012;33(1):9-15.

10. Van Damme L, Ramjee G, Alary M, Vuylsteke B, Chandeying V, Rees H, et al. Effectiveness of COL-1492, a nonoxynol-9 vaginal gel, on HIV-1 transmission in female sex workers: a randomised controlled trial. Lancet. 2002;360:971-7.

11. Baral S, Beyrer C, Muessig K, Poteat T, Wirtz AL, Decker MR, et al. Burden of HIV among female sex workers in low-income and middle-income countries: a systematic review and metaanalysis. Lancet Infect Dis. 2012;12(7):538-49.

12. Stroup DF, Berlin JA, Morton SC, Olkin I, Williamson GD, Rennie D, et al. Meta-analysis of observational studies in epidemiology: a proposal for reporting. Meta-analysis Of Observational Studies in Epidemiology (MOOSE) group. JAMA. 2000;283(15):2008-12.

13. Borenstein M, Higgins JPT. Meta-analysis and subgroups. Prev Sci. 2013;14(2):134-43.

14. Higgens JPT, Green S, editors. Cochrane handbook for systematic reviews of interventions. Version 5.1.0. The cochrane collaboration; 2011. Avalibale from www.handbook.cochrane.org.

15. Ioannidis JPA, Patsopoulos NA, Rothstein HR. Reasons or excuses for avoiding meta-analysis in forest plots. BMJ. 2008;336(7658):1413-5.

16. van Houwelingen HC, Arends LR, Stijnen T. Advanced methods in meta-analysis: multivariate approach and meta-regression. Stat Med. 2002;21(4):589-624.

17. Hedges LV, Olkin I. Statistical methods for meta-analysis. Cambridge: Academic Press; 1985.

18. Viechtbauer W, Viechtbauer W. Conducting meta-analyses in R with the metafor package. J Stat Softw. 2010;36(3):1-48.

19. Team RC. R: a language and environment for statistical computing. R Foundation for Statistical Computing, Vienna, Austria. ISBN 3-900051-07-0, URL. Vienna; 2018. http://www.R-proje ct.org/.

20. Sedgwick P. Meta-analyses: tests of heterogeneity. BMJ. 2012;13(344):e3971.

21. Higgins JPT, Thompson SG, Deeks JJ, Altman DG. Measuring inconsistency in meta-analyses. BMJ. 2003;327(7414):557-60.

22. Koblin BA, Hoover DR, Xu G, Frye V, Latka MH, Lucy D, et al. Correlates of anal intercourse vary by partner type among substance-using women: baseline data from the UNITY study. AIDS Behav. 2010;14(1):132-40.
23. Hanck SE, Blankenship KM, Irwin KS, West BS, Kershaw T. Assessment of self-reported sexual behavior and condom use among female sex workers in India using a polling box approach: a preliminary report. Sex Transm Dis. 2008;35(5):489-94.

24. Creighton S, Tariq S, Perry G. Sexually transmitted infections among UK street-based sex workers. Sex Transm Infect. 2008;84(1):32-3.

25. Deschamps MM, Zorrilla CD, Morgan CA, Donastorg Y, Metch B, Madenwald T, et al. Recruitment of Caribbean female commercial sex workers at high risk of HIV infection. Rev Panam Salud Publica. 2013;34(2):92-8.

26. Ramjee G, Weber A, Morar N. Recording sexual behavior: comparison of recall questionnaires with a coital diary. Sex Transm Dis. 1999;26(7):374-80.

27. Van der Elst EM, Okuku HS, Nakamya P, Muhaari A, Davies A, Mcclelland S, et al. Is Audio computer-assisted self-interview (ACASI) useful in risk behaviour assessment of female and male sex workers, Mombasa, Kenya? PLoS ONE. 2009;4(5):1-10.

28. Hladik W, Baughman AL, Serwadda D, Tappero JW, Kwezi R, Nakato ND, et al. Burden and characteristics of HIV infection among female sex workers in Kampala, Uganda-a respondentdriven sampling survey. BMC Public Health. 2017;17(1):565.

29. Schwandt M, Morris C, Ferguson A. Anal and dry sex in commercial sex work, and relation to risk for sexually transmitted infections and HIV in Meru, Kenya. Sex Transm Infect. 2006;82:392-6.

30. Bradley J, Rajaram S, Alary M, Isac S, Washington R, Moses $\mathrm{S}$, et al. Determinants of condom breakage among female sex workers in Karnataka, India. BMC Public Health. 2011;11(Suppl 6):S14.

31. Marek E, Dergez T, D'cruz G, Bozsa S, Cseh A, Szilard I, et al. Human papillomavirus infections among Hungarian female sex workers. Eur J Cancer Care (Engl). 2014;23(1):65-75.

32. Markosyan KM, Babikian T, DiClemente RJ, Hirsch JS, Grigoryan S, del Rio C. Correlates of HIV risk and preventive behaviors in Armenian female sex workers. AIDS Behav. 2007;11(2):325-34.

33. Bradley J, Rajaram S, Moses S, Gowda GC, Pushpalatha R, Ramesh BM, et al. Female sex worker client behaviors lead to condom breakage: a prospective telephone-based survey in Bangalore, South India. AIDS Behav. 2012;17(2):559-67.

34. Van De Perre P, Carael M, Robert-Guroff M. Female prostitutes: a risk group for infection with human T-cell lymphotropic virus type III. Lancet. 1985;2(8454):524-7.

35. Voeten H, Egesah OB, Varkevisser CM, Habbema JDF. Female sex workers and unsafe sex in urban and rural Nyanza, Kenya: regular partners may contribute more to HIV transmission than clients. Trop Med Int Health. 2007;12(2):174-82.

36. Carney T, Petersen Williams PM, Parry CDH. Ithubalethuintervention to address drug use and sexual HIV risk patterns among female commercial sex workers in Durban, South Africa. J Psychoact Drugs. 2016;48(4):303-9.

37. Owen BN, Elmes J, Silhol R, Dang Q, McGowan I, Shacklett B, et al. How common and frequent is heterosexual anal intercourse among South Africans? A systematic review and meta-analysis. J Int AIDS Soc. 2017;19(1):1-14.

38. Owen BN, Brock PM, Butler AR, Pickles M, Brisson M, Baggaley RF, et al. Prevalence and frequency of heterosexual anal intercourse among young people: a systematic review and metaanalysis. AIDS Behav. 2015;19(7):1338-60.

39. Matheou A. A blind spot in HIV prevention-female anal sex. Issue Brief. Available from: http://www.aidsallianceind ia.net $/$ q $=$ node $/ 40$ andpid $=173$.

40. Beattie TSH, Bradley JE, Vanta UD, Lowndes CM, Alary M. Vulnerability re-assessed: the changing face of sex work in Guntur district, Andhra Pradesh. AIDS Care. 2013;25(3):378-84. 
41. Duby Z, Colvin C. Conceptualizations of heterosexual anal sex and HIV risk in five East African communities. J Sex Res. 2014;51(8):863-73.

42. Hawkes S, Collumbien M, Platt L, Lalji N, Rizvi N, Andreasen A, et al. HIV and other sexually transmitted infections among men, transgenders and women selling sex in two cities in Pakistan: a cross-sectional prevalence survey. Sex Transm Infect. 2009;85(Suppl 2):ii8-16.

43. Roth AM, Hensel DJ, Fortenberry JD, Garfein RS, Gunn JKL, Wiehe SE. Feasibility and acceptability of cell phone diaries to measure HIV risk behavior among female sex workers. AIDS Behav. 2014;18(12):2314-24.

44. Duby Z, Hartmann M, Mahaka I, Munaiwa O, Nabukeera J, Vilakazi N, et al. Lost in translation: language, terminology, and understanding of penile-anal intercourse in an HIV prevention trial in South Africa, Uganda, and Zimbabwe. J Sex Res. 2015;53(9):1096-106.

45. Priddy F, Wakasiaka S. Anal sex, vaginal practices, and HIV incidence in female sex workers in urban Kenya: implications for the development of intravaginal HIV prevention methods. AIDS Res Hum Retrovir. 2011;27(10):1067-72.

46. Halperin DT, de Moya EA, Pérez-Then E, Pappas G, Garcia Calleja JM. Understanding the HIV epidemic in the Dominican Republic: a prevention success story in the Caribbean? J Acquir Immune Defic Syndr. 2009;51(Suppl 1):S52-9.

47. Patra RK, Mahapatra B, Kovvali D, Proddutoor L, Saggurti N. Anal sex and associated HIV-related sexual risk factors among female sex workers in Andhra Pradesh, India. Sex Health. 2012;9(5):430-7.

48. Veldhuijzen NJ, Ingabire C, Luchters S, Bosire W, Braunstein S, Chersich M, van der Wijgert J. Anal intercourse among female sex workers in East Africa is associated with other high-risk behaviours for HIV. Sex Health. 2011;8:251-4.

49. Ramjee G, Williams B, Gouws E, Van Dyck E, De Deken B, Karim SA. The impact of incident and prevalent herpes simplex virus-2 infection on the incidence of HIV-1 infection among commercial sex workers in South Africa. J Acquir Immune Defic Syndr. 2005;39(3):333-9.

50. Dunkle KL, Beksinska ME, Rees VH, Ballard RC, Htun Y, Wilson ML. Risk factors for HIV infection among sex workers in Johannesburg, South Africa. Int J STD AIDS. 2005; 16(3):256-61.

51. Ferguson AMC. Assessing the role of anal intercourse in the epidemiology of AIDS in Africa (Letter to the Editor). Int J Epidemiol. 2003;14:856.

52. Fonck K, Kaul R, Mph JK, Keli F, Macdonald KS, Ronald AR, et al. A randomized, placebo-controlled trial of monthly azithromycin prophylaxis to prevent sexually transmitted infections and HIV-1 in Kenyan sex workers: study design and baseline findings. Int J STD AIDS. 2000;11:804-11.

53. Abdool Karim S, Ramjee G. Anal sex and HIV tranmission in women. Am J Public Health. 1998;88(8):1265-6.

54. Laga M, Monoka A, Kivuvu M, Malele B, Tuliza M, Nzila N, Goeman JBF. Non-ulcerative sexually transmitted diseases as risk factors for HIV-1 transmission in women: reults from a cohort study. AIDS. 1993;7:95-102.

55. Ghys P, Diallo M, Ettiegne-Traore V. Effect of interventions to control sexually transmitted disease on the incidence of HIV iinfection in female sex workers. AIDS. 2001;15:1421-31.

56. Karim QA, Karim SSA, Sa F, Ch M, Soldan K, Zondi M. Reducing the risk of HIV infection among South African sex workers: socioeconomic and gender barriers. Am J Public Health. 1995;85(11):1521-4.

57. Cai Y, Shi R, Shen T, Pei B, Jiang X, Ye X, et al. A study of HIV/AIDS related knowledge, attitude and behaviors among female sex workers in Shanghai China. BMC Public Health. 2010;10:377.

58. Das A, Prabhakar P, Narayanan P, Neilsen G, Wi T, Kumta $\mathrm{S}$, et al. Prevalence and assessment of clinical management of sexually transmitted infections among female sex workers in two cities of India. Infect Dis Obstet Gynecol. 2011; 2011:494769.

59. Reed E, Gupta J, Biradavolu M, Devireddy V, Blankenship KM. The context of economic insecurity and its relation to violence and risk factors for HIV among female sex workers in Andhra Pradesh, India. Public Health Rep. 2010;125(Suppl):81-9.

60. Todd CS, Nasir A, Stanekzai MR, Bautista CT, Botros BA, Scott PT, et al. HIV, hepatitis B, and hepatitis C prevalence and associated risk behaviors among female sex workers in three Afghan cities. AIDS. 2010;24(Suppl 2):S69-75.

61. Bautista CT, Pando MA, Reynaga E, Marone R, Sateren WB, Montano SM, et al. Sexual practices, drug use behaviors, and prevalence of HIV, syphilis, hepatitis B and C, and HTLV-1/2 in immigrant and non-immigrant female sex workers in Argentina. J Immigr Minor Health. 2009;11(2):99-104.

62. Raj A, Saggurti N, Cheng DM, Dasgupta A, Bridden C, Pradeshi M, et al. Transactional sex risk and STI among HIVinfected female sex workers and HIV-infected male clients of FSWs in India. AIDS Care. 2011;23(13):1374-81.

63. Beattie TSH, Bhattacharjee P, Ramesh BM, Gurnani V, Anthony J, Isac S, et al. Violence against female sex workers in Karnataka state, south India: impact on health, and reductions in violence following an intervention program. BMC Public Health. 2010;10(1):476.

64. Azim T, Chowdhury EI, Reza M, Ahmed M, Uddin MT, Khan $\mathrm{R}$, et al. Vulnerability to HIV infection among sex worker and non-sex worker female injecting drug users in Dhaka, Bangladesh: evidence from the baseline survey of a cohort study. Harm Reduct J. 2006;3:33.

65. Dandona R, Dandona L, Gutierrez JP, Kumar AG, McPherson S, Samuels F, et al. High risk of HIV in non-brothel based female sex workers in India. BMC Public Health. 2005;5:87.

66. Caterino-De-Araujo A, De Los Santos Fortuna E. Seropositivity to chlamydia trachomatis in prostitutes: relationship to other sexually transmitted diseases (STDs). Braz J Med Biol Res. 1990;23:697-700.

67. Rugpao S, Pruithithada N, Yutabootr Y, Prasertwitayakij W, Tovanabutra S. Condom breakage during commercial sex in Chiang Mai, Thailand. Contraception. 1993;48(6):537-47.

68. Wirawan DN, Fajans P, Ford K. AIDS and STDs: risk behaviour patterns among female sex workers in Bali, Indonesia. AIDS Care. 1993;5(3):289-303.

69. Swaddiwudhipong W, Nguntra P, Chaovakiratipong C, Koonchote S, Lerdlukanavonge P, Chandoun C. Effect of health education and condom promotion on behavioral change among low socioeconomic prostitutes in Mae Sot, Tak, Thailand. Southeast Asian J Trop Med Public Health. 1990;21(3):453-7.

70. Jana S, Chakraborty AK, Das A, Khodakevich L, Chakraborty M, Pal NK. Community based survey of STD/HIV infection among commercial sex-workers in Calcutta, India. J Commun Dis. 1994;26(3):168-71.

71. Decker MR, Wirtz AL, Baral SD, Peryshkina A, Mogilnyi V, Weber RA, et al. Injection drug use, sexual risk, violence and STI/HIV among Moscow female sex workers. Sex Transm Infect. 2012;88(4):278-83.

72. Wong M-L, Chan R, Tan HH, Yong E, Lee L, Cutter J, et al. Sex work and risky sexual behaviors among foreign entertainment workers in urban Singapore: findings from mystery client survey. J Urban Health. 2012;89(6):1031-44. 
73. Seib C, Dunne MP, Fischer J, Najman JM. Commercial sexual practices before and after legalization in Australia. Arch Sex Behav. 2010;39(4):979-89.

74. van Veen MG, Götz HM, van Leeuwen PA, Prins M, van de Laar MJW. HIV and sexual risk behavior among commercial sex workers in the Netherlands. Arch Sex Behav. 2010;39(3):714-23.

75. Weber AE, Boivin J-F, Blais L, Haley N, Roy E. HIV risk profile and prostitution among female street youths. J Urban Health. 2002;79(4):525-35.

76. Philpot CR, Harcourt CL, Edwards JM. A survey of female prostitutes at risk of HIV infection and other sexually transmissible diseases. Sex Transm Infect. 1991;67(5):384-8.

77. Pineda J, Aguado I, Rivero A, Vergara A. HIV-1 infection among non-intravenous drug user female prostitutes in Spain. No evidence of evolution to Pattern II. AIDS. 1992;6:1365-9.

78. Mak R, Plum J. Do prostitutes need more health education regarding sexually transmitted diseases and the HIV infection? Experience in a Belgian city. Soc Sci Med. 1991;33(8):963-6.

79. Modan B, Goldschmidt R, Rubinstein E, Vonsover A, Zinn M, Golan R, et al. Prevalence of HIV antibodies in transsexual and female prostitutes. Am J Public Health. 1992;82(4):590-2.

80. van Haastrecht HJ, Fennema JS, Coutinho RA, van der Helm TC, Kint JA, van den Hoek JA. HIV prevalence and risk behaviour among prostitutes and clients in Amsterdam: migrants at increased risk for HIV infection. Genitourin Med. 1993;69(4):251-6.

81. Gossop M, Powis B, Griffiths P, Strang J. Female prostitutes in south London: use of heroin, cocaine and alcohol, and their relationship to health risk behaviours. AIDS Care. 1995;7(3):253-60.

82. Ward H, Day S, Mezzone J, Dunlop L, Donegan C, Farrar S, et al. Prostitution and risk of HIV: female prostitutes in London. BMJ. 1993;307(6900):356-8.

83. Kelly-Hanku A, Rawstorne P, Kupul M, Worth H, Shih P, Man WYN. Anal sex, vaginal sex and HIV risk among female sex workers in Papua New Guinea. AIDS Behav. 2014;18(3):573-82.

84. Alexander M, Mainkar M, Deshpande S, Chidrawar S, Sane S, Mehendale $\mathrm{S}$. Heterosexual anal sex among female sex workers in high HIV prevalence states of India: need for comprehensive intervention. PLoS ONE. 2014;9(2):e88858.

85. Mishra S, Thompson LH, Sonia A, Khalid N, Emmanuel F, Blanchard JF. Sexual behaviour, structural vulnerabilities and HIV prevalence among female sex workers in Pakistan. Sex Transm Infect. 2013;89(Suppl 2):ii34-42.

86. Decker MR, Wirtz AL, Moguilnyi V, Peryshkina A, Ostrovskaya M, Nikita M, et al. Female sex workers in three cities in Russia: HIV prevalence, risk factors and experience with targeted HIV prevention. AIDS Behav. 2014;18(3):562-72.

87. Kinsler JJ, Blas MM, Cabral A, Carcam C, Halsey N, Brown $\mathrm{B}$, et al. Understanding STI risk and condom use patterns by partner type among female sex workers in Peru. Open AIDS J. 2015;8:17-20.

88. Brahme R, Mehta S, Sahay S, Joglekar N, Ghate M, Joshi S, et al. Correlates and trend of HIV prevalence among female sex workers attending sexually transmitted disease clinics in Pune, India (1993-2002). J Acquir Immune Defic Syndr. 2006;41(1):107-13.

89. Ngugi EN, Wilson D, Sebstad J, Plummer FA, Moses S. Focused peer-mediated educational programs among female sex workers to reduce sexually transmitted disease and human immunodeficiency virus transmission in Kenya and Zimbabwe. J Infect Dis. 1996;174(Supp 2):S240-7.

90. van Gemert C, Stoove M, Kwarteng T, Bulu S, Bergeri I, Wanyeki I, et al. Chlamydia prevalence and associated behaviours among female sex workers in Vanuatu: results from an integrated biobehavioural survey, 2011. AIDS Behav. 2014;18(10):2040-9.
91. Juárez-Figueroa L, Uribe-Salas F, Conde-Glez C, HernándezAvila M, Olamendi-Portugal M, Uribe-Zúñiga P, et al. Low prevalence of hepatitis B markers among Mexican female sex workers. Sex Transm Infect. 1998;74(6):448-50.

92. Wong ML, Chan R, Lee J, Koh D, Wong C. Controlled evaluation of a behavioural intervention programme on condom use and gonorrhoea incidence among sex workers in Singapore. Health Educ Res. 1996;11(4):423-32.

93. Westhoff W, McDermott R, Holcomb D. HIV-related knowledge and behavior of commercial sex workers: a tale of three cities. Int Electron J Health Educ. 2000;3(1):55-63.

94. Qu S, Liu W, Choi K-H, Li R, Jiang D, Zhou Y, et al. The potential for rapid sexual transmission of HIV in China: sexually transmitted diseases and condom failure highly prevalent among female sex workers. AIDS Behav. 2002;6(3):267-75.

95. Kazerooni PA, Motazedian N, Motamedifar M, Sayadi M, Sabet M, Lari MA, et al. The prevalence of human immunodeficiency virus and sexually transmitted infections among female sex workers in Shiraz, South of Iran: by respondent-driven sampling. Int J STD AIDS. 2014;25(2):155-61.

96. Katsulis Y, Durfee A. Prevalence and correlates of sexual risk among male and female sex workers in Tijuana, Mexico. Glob Public Health. 2012;7(4):367-83.

97. Kassaian N, Ataei B, Yaran M, Babak A, Shoaei P. Hepatitis $\mathrm{B}$ and $\mathrm{C}$ among women with illegal social behavior in Isfahan, Iran: Seroprevalence and associated factors. Hepat Mon. 2011;11(5):368-71.

98. Decker MR, McCauley HL, Phuengsamran D, Janyam S, Seage GR, Silverman JG. Violence victimisation, sexual risk and sexually transmitted infection symptoms among female sex workers in Thailand. Sex Transm Infect. 2010;86(3):236-40.

99. Ojeda VD, Strathdee SA, Lozada R, Rusch MLA, Fraga M, Orozovich P, et al. Associations between migrant status and sexually transmitted infections among female sex workers in Tijuana, Mexico. Sex Transm Infect. 2009;85(6):420-6.

100. Nguyen TV, Van Khuu N, Le Thi TT, Nguyen AP, Cao V, Tham DC, et al. Sexually transmitted infections and risk factors for gonorrhea and chlamydia in female sex workers in Soc Trang, Vietnam. Sex Transm Dis. 2008;35(11):935-40.

101. Allen CF, Edwards M, Williamson LM, Kitson-Piggott W, Wagner H-U, Camara B, et al. Sexually transmitted infection service use and risk factors for HIV infection among female sex workers in Georgetown, Guyana. J Acquir Immune Defic Syndr. 2006;43(1):96-101.

102. Sarkar K, Bal B, Mukherjee R, Saha MK, Chakraborty S, Niyogi SK, et al. Young age is a risk factor for HIV among female sex workers-an experience from India. J Infect. 2006;53(4):255-9.

103. Sarkar K, Bal B, Mukherjee R, Niyogi SK, Saha MK, Bhattacharya SK. Epidemiology of HIV infection among brothelbased sex workers in Kolkata, India. J Health Popul Nutr. 2005;23(3):231-5.

104. Augusto Â do R, Young PW, Horth RZ, Inguane C, Sathane I, Ngale K, et al. High burden of HIV infection and risk behaviors among female sex Workers in three main urban areas of mozambique. AIDS Behav. 2016;20(4):799-810.

105. Grosso AL, Ketende S, Dam K, Papworth E, Ouedraogo HG, KyZerbo O, et al. Structural determinants of health among women who started selling sex as minors in Burkina Faso. JAIDS J Acquir Immune Defic Syndr. 2015;1(68):S162-70.

106. Decker MR, Miller E, McCauley HL, Tancredi DJ, Levenson RR, Waldman J, et al. Sex trade among young women attending family-planning clinics in Northern California. Int J Gynaecol Obstet. 2012;117(2):173-7.

107. Edwards JM, Iritani BJ, Hallfors DD. Prevalence and correlates of exchanging sex for drugs or money among adolescents in the United States. Sex Transm Infect. 2006;82(5):354-8. 
108. Jeal N, Salisbury C. Health needs and service use of parlourbased prostitutes compared with street-based prostitutes: a crosssectional survey. BJOG. 2007;114(7):875-81.

109. Remis RS, Kang L, Calzavara L, Pan Q, Liu J, Myers T, et al. Prevalence and correlates of HIV infection and sexually transmitted infections in female sex workers (FSWs) in Shanghai,China. Epidemiol Infect. 2015;143(2):258-66.

110. Ruan Y, Cao X, Qian H-Z, Zhang L, Qin G, Jiang Z, et al. Syphilis among female sex workers in Southwestern China: potential for HIV transmission. Sex Transm Dis. 2006;33(12):719-23.

111. Suryawanshi D, Sharma V, Saggurti N, Bharat S. Factors associated with the likelihood of further movement among mobile female sex workers in India: a multinomial logit approach. J Biosoc Sci. 2016;48(04):539-56.

112. Wang B, Li X, Stanton B, Yang H, Fang X, Zhao R, et al. Vaginal douching, condom use, and sexually transmitted infections among Chinese female sex workers. Sex Transm Dis. 2005;32(11):696-702.

113. van den Hoek A, Yuliang F, Dukers NH, Zhiheng C, Jiangting F, Lina Z, et al. High prevalence of syphilis and other sexually transmitted diseases among sex workers in China: potential for fast spread of HIV. AIDS. 2001;15(6):753-9.

114. Wong HTH, Lee KCK, Chan DPC. Community-based sexually transmitted infection screening and increased detection of pharyngeal and urogenital chlamydia trachomatis and neisseria gonorrhoeae infections in female sex workers in Hong Kong. Sex Transm Dis. 2015;42(4):185-91.

115. Chan MKT, Ho KM, Lo KK. A behaviour sentinel surveillance for female sex workers in the Social Hygiene Service in Hong Kong (1999-2000). Int J STD AIDS. 2002;13(12):815-20.

116. Taghizadeh H, Taghizadeh F, Fathi M, Reihani P, Shirdel N, Rezaee SM. Drug use and high-risk sexual behaviors of women at a drop-in center in Mazandaran Province, Iran, 2014. Iran J Psychiatry Behav Sci. 2015;9(2):e1047.

117. Vall-Mayans M, Villa M, Saravanya M, Loureiro E, Meroño M, Arellano E, et al. Sexually transmitted Chlamydia trachomatis, Neisseria gonorrhoeae, and HIV-1 infections in two at-risk populations in Barcelona: female street prostitutes and STI clinic attendees. Int J Infect Dis. 2007;11(2):115-22.

118. Tamene MM, Tessema GA, Beyera GK. Condom utilization among female sex workers in Northwest Ethiopia: a cross-sectional study. Pan Afr Med J. 2015;21:50.

119. Martin HL, Nyange PM, Richardson BA, Lavreys L, Mandaliya K, Jackson DJ, et al. Hormonal contraception, sexually transmitted diseases, and risk of heterosexual transmission of human immunodeficiency virus type 1. J Infect Dis. 1998;178(4):1053-9.

120. McKeganey N, Barnard M, Leyland A, Coote I, Follet E. Female streetworking prostitution and HIV infection in Glasgow. BMJ. 1992;305(6857):801-4.

121. Hakre S, Arteaga G, Núñez AE, Bautista CT, Bolen A, Villarroel M, et al. Prevalence of HIV and other sexually transmitted infections and factors associated with syphilis among female sex workers in Panama. Sex Transm Infect. 2013;89(2):156-64.

122. Thuy NT, Nhung VT, Thuc NV, Lien TX, Khiem HB. HIV infection and risk factors among female sex workers in southern Vietnam. AIDS. 1998;12(4):425-32.

123. Bokhari A, Nizamani NM, Jackson DJ, Rehan NE, Rahman M, Muzaffar R, et al. HIV risk in Karachi and Lahore, Pakistan: an emerging epidemic in injecting and commercial sex networks. Int J STD AIDS. 2007;18(7):486-92.

124. Bhatta P, Thapa S, Neupane S, Baker J, Friedman M. Commercial sex workers in Kathmandu Valley: profile and prevalence of sexually transmitted diseases. JNMA J Nepal Med Assoc. 1994;32(111):191-203.
125. Ryan KA, Roddy RE, Zekeng L, Weir SS, Tamoufé U. Characteristics associated with prevalent HIV infection among a cohort of sex workers in Cameroon. Sex Transm Infect. 1998;74(2):131-5.

126. Anteneh ZA, Agumas YA, Tarekegn M. Sexually transmitted diseases among female commercial sex workers in Finote Selam town, northwest Ethiopia: a community-based cross-sectional study. HIV/AIDS Res Palliat Care. 2017;9:43-9.

127. Trani F, Altomare C, Nobile CGA, Angelillo IF. Female sex street workers and sexually transmitted infections: their knowledge and behaviour in Italy. J Infect. 2006;52(4):269-75.

128. Seidlin M, Krasinski K, Bebenroth D, Itri V, Paolino AM, Valentine F. Prevalence of HIV infection in New York call girls. J Acquir Immune Defic Syndr. 1988;1(2):150-4.

129. Day S, Ward H, Harris JR. Prostitute women and public health. BMJ. 1988;297(6663):1585.

130. Wilson D, Sibanda B, Mboyi L, Msimanga S, Dube G. A pilot study for an HIV prevention programme among commercial sex workers in Bulawayo, Zimbabwe. Soc Sci Med. 1990;31(5):609-18.

131. Zapiola I, Salomone S, Alvarez A, Scolastico MC, Koessel RA, Lemus J, et al. HIV-1, HIV-2, HTLV-I/II and STD among female prostitutes in Buenos Aires, Argentina. Eur J Epidemiol. 1996;12(1):27-31.

132. Wong ML, Chan RKW, Chua WL, Wee S. Sexually transmitted diseases and condom use among female freelance and brothel-based sex workers in Singapore. Sex Transm Dis. 1999;26(10):593-600.

133. Spina M, Serraino D, Tirelli U. Condom use and high-risk sexual practices of female prostitutes in Italy. AIDS. 1992;6(6):601-2.

134. Rehle T, Brinkmann UK, Siraprapasiri T, Coplan P, Aiemsukawat C, Ungchusak K. Risk factors of HIV-1 infection among female prostitutes in Khon Kaen, northeast Thailand. Infection. 1992;20(6):328-31.

135. Plumridge EW, Abel G. A "segmented" sex industry in New Zealand: sexual and personal safety of female sex workers. Aust N Z J Public Health. 2001;25(1):78-83.

136. Bugssa G, Dessalegn B, Dimtsu B, Berhane Y. Prevalence and factors associated with HIV and hepatitis B virus infections among female commercial sex workers in mekelle, Ethiopia: Cross sectional study. Int J Pharm Sci Res. 2015;6(1):135-46.

137. Krogsgaard K, Gluud C, Pedersen C, Nielsen JO, Juhl E, Gerstoft $\mathrm{J}$, et al. Widespread use of condoms and low prevalence of sexually transmitted diseases in Danish non-drug addict prostitutes. Br Med J (Clin Res Ed). 1986;293(6560):1473-4.

138. van den Hoek JA, Coutinho RA, van Haastrecht HJ, van Zadelhoff AW, Goudsmit J. Prevalence and risk factors of HIV infections among drug users and drug-using prostitutes in Amsterdam. AIDS. 1988;2(1):55-60.

139. Golenbock D, Guerra J, Pfister J, Golubjatnikov R, Tejada A, Abugattas J, et al. Absence of infection with human immunodeficiency virus in peruvian prostitutes. AIDS Res Hum Retrovir. 1988;4(6):493-9.

140. Medhi GK, Mahanta J, Paranjape RS, Adhikary R, Laskar N, Ngully P. Factors associated with HIV among female sex workers in a high HIV prevalent state of India. AIDS Care. 2012;24(3):369-76.

141. Valadez JJ, Berendes S, Jeffery C, Thomson J, Benothman H, Danon L, et al. Filling the knowledge gap: measuring HIV prevalence and risk factors among men who have sex with men and female sex workers in Tripoli, Libya. Polis MA, editor. PLoS ONE. 2013;8(6):e66701.

142. Trevisol FS, Da Silva MV. HIV frequency among female sex workers in Imbituba, Santa Catarina, Brazil. Braz J Infect Dis. 2005;9(6):500-5. 
143. Sagtani RA, Bhattarai S, Adhikari BR, Baral D, Yadav DK, Pokharel PK. Alcohol use, HIV risk behavior and experience of sexually transmitted infections among female sex workers of Nepal. Clin Epidemiol Glob Health. 2013;1(2):73-8.

144. Parcesepe AM, Toivgoo A, Chang M, Riedel M, Carlson C, DiBennardo R, et al. Physical and sexual violence, childhood sexual abuse and HIV/STI risk behaviour among alcohol-using women engaged in sex work in Mongolia. Glob Public Health. 2015;10(1):88-102.

145. Stanekova D, Jiresova K, Habekova M, Wimmerova S, Cuitti M, Vavrincikova L, et al. HIV infection and risk behaviour of commercial sex workers and intravenous drug users in Slovakia. Cent Eur J Public Health. 2004;12(4):197-200.

146. Mann JM, Nzilambi N, Piot P, Bosenge N, Kalala M, Francis H, Colebunders RC, Azila PK, Curran JWQT. HIV infection and associated risk factors in female prostitutes in Kinshasa, Zaire. AIDS. 1988;2:249-54.

147. Kakar SR, Biggs K, Chung C, Sawleshwarkar S, Mindel A, Lagios K, et al. A retrospective case note review of sex worker attendees at sexual health clinics in the western suburbs of Sydney. Sex Health. 2010;7(1):3-7.

148. Van Haastrecht HJA, Van den Hoek JAR, Coutinho RA. Evidence for a change in behaviour among heterosexuals in Amsterdam under the influence of AIDS. Genitourin Med. 1991;67(3):199-206.

149. Weinberg MS, Shaver FM, Williams CJ. Gendered sex work in the San Francisco tenderloin. Arch Sex Behav. 1999;28(6):503-21.

150. Kaptue L, Zekeng L, Djoumessi S, Monny-Lobe M, Nichols D, Debuysscher R. HIV and chlamydia infections among prostitutes in Yaounde, Cameroon. Genitourin Med. 1991;67(2):143-5.

151. Johnson BL, Von Haeften I, Fishbein M, Kasprzyk D, Montano D. Factors influencing IDU and non-IDU female commercial sex workers' intentions to always use condoms for vaginal sex with their regular partner. Psychol Health Med. 2001;6(2):207-22.
152. De Meis C, De Vasconcellos ACP, Linhares D, Andrada-Serpa MJ. HIV-1 infection among prostitutes in Rio de Janeiro, Brazil. AIDS. 1991;5(2):236-7.

153. Coetzee J, Hunt G, Jaffer M, Otwombe K, Scott L, Bongwe A, et al. HIV-1 viraemia and drug resistance amongst female sex workers in Soweto, South Africa: A cross sectional study. SluisCremer N, editor. PLoS ONE. 2017;12(12):e0188606.

154. Longo JDD, Simaleko MM, Diemer HS-C, Grésenguet G, Brücker G, Belec L. Risk factors for HIV infection among female sex workers in Bangui, Central African Republic. Paz-Bailey G, editor. PLoS ONE. 2017;12(11):e0187654.

155. Sileo KM, Kintu M, Kiene SM. The intersection of intimate partner violence and HIV risk among women engaging in transactional sex in Ugandan fishing villages. AIDS Care. 2018;30(4):444-52.

156. Cepeda A, Nowotny KM. A border context of violence: Mexican female sex workers on the U.S.-Mexico border. Alvirez Arsenault, Barajas, Barnard, Beattie, Bucardo, Canas, Castaneda, Castillo, Castillo, Cepeda, Cepeda, Choi, Church, Connell, Connell, Curtis, Dalla, del Rio, Denzin, Dunkle, El-Bassel, Farley, Farley, Farley, Finnegan, Fuller, Galanti, Gerson, Hon A, editor. Violence Against Women. 2014;20(12):1506-31.

157. De Dieu Longo J, Simaleko MM, Ngbale R, Gresenguet G, Brucker G, Belec L. Spectrum of female commercial sex work in Bangui, Central African Republic. Ahoyo Bekker, Berthe, Blanchard, Blankhart, Bryant, Busza, Choi, Cooper, Das, Decosas, Dhana, Ferguson, Fritz, Ghys, Gresenguet, Gresenguet, Harcourt, Ikpeazu, Kayembe, Kimani, Laga, LeGoff, Low, MacAllister, Mahdavi, Martin, Mathiot, Mbopi-Keou, Mbousso A, editor. SAHARA-J J Soc Asp HIV/AIDS. 2017;14(1):171-84.

Publisher's Note Springer Nature remains neutral with regard to jurisdictional claims in published maps and institutional affiliations.

\section{Affiliations}

\section{Branwen Nia Owen ${ }^{1}\left(\right.$ D Rebecca F. Baggaley ${ }^{2}$. Jocelyn Elmes ${ }^{1,2} \cdot$ Amy Harvey $^{1} \cdot$ Zara Shubber $^{1} \cdot$ Ailsa R. Butler $^{1}$. Romain Silhol $^{1} \cdot$ Peter Anton $^{3} \cdot$ Barbara Shacklett $^{4} \cdot$ Ariane van der Straten $^{5,6} \cdot$ Marie-Claude Boily $^{1}$}

Rebecca F. Baggaley

Rebecca.baggaley@1shtm.ac.uk

Jocelyn Elmes

Jocelyn.elmes@1shtm.ac.uk

Amy Harvey

Amy.harvey14@imperial.ac.uk

Zara Shubber

zarashubber@gmail.com

Ailsa R. Butler

ailsabutler@btinternet.com

Romain Silhol

r.silhol@imperial.ac.uk

Peter Anton

panton@mednet.ucla.edu

Barbara Shacklett

blshacklett@ucdavis.edu

Ariane van der Straten

ariane@rti.org
Marie-Claude Boily

mc.boily@imperial.ac.uk

1 Department of Infectious Disease Epidemiology, Imperial College London, Norfolk Place, St Mary's Campus, Praed Street, London W2 1NY, UK

2 Department of Global Health and Development, London School of Hygiene and Tropical Medicine, London, UK

3 Department of Medicine, David Geffen School of Medicine, UCLA, Los Angeles, USA

4 Department of Medical Microbiology and Immunology, University of California, Davis, USA

5 Women's Global Health Imperative Program, RTI International, San Francisco, USA

6 Department of Medicine, Center for AIDS Prevention Studies, UCSF, San Francisco, USA 